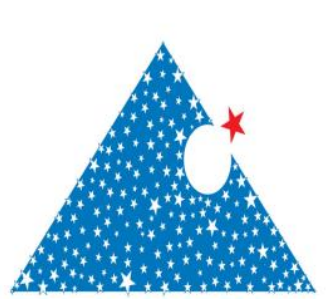

www.dergipark.gov.tr

ISSN:2148-3736

El-Cezerî Fen ve Mühendislik Dergisi

Cilt: 4, No: 3, 2017 (593-597)

El-Cezerî Journal of Science and

Engineering

Vol: 4, No: 3, 2017 (593-597)

\title{
ECJSE
}

Research Paper / Makale

\section{Determination of Temperature Gradient in TIG Welding of Duplex Stainless Steel}

\author{
Alptekin KISASÖZ, Rıdvan GECÜ, Ahmet KARAASLAN \\ Yıldız Teknik Üniversitesi, Kimya Metalurji Fakültesi, Metalurji ve Malzeme Mühendisliği Bölümü, 34210 \\ İstanbul/TÜRKIYYE; email: akisasoz@gmail.com
}

\begin{abstract}
In welding of DSS, austenite/ferrite phase ratio can vary and various intermetallic phases may occur in weld metal due to excessive heat input. Especially, HAZ is very sensitive against the variation of austenite/ferrite phase ratio and formation of intermetallic phases. Thus, determining the temperature gradient in welding is very crucial. In this study ANSYS workbench was used for defining the temperature gradient in HAZ. The peak temperature in HAZ generated during the welding was determined and also, cooling rates of the analysis were compared with theoretical cooling rate values.
\end{abstract}

Keywords: Finite element modelling, ANSYS, TIG welding.

\section{Çift Fazlı Paslanmaz Çeliklerin TIG Kaynağında Sıcaklık Eğimcesinin Belirlenmesi}

\begin{abstract}
Özet: Çift fazlı paslanmaz çeliklerin kaynağında, yüksek 1sı girdisine bağlı olarak ferrit/östenit faz dengesi değişmekte ve çeşitli intermetalik fazlar oluşabilmektedir. Özellikle, 1sı etkisi altındaki bölge (IEAB) ferrit/östenit faz dengesinin değişimine ve intermetalik faz oluşumuna karşı oldukça hassastır. Bu nedenle kaynak işlemi sırasında özellikle IEAB'de oluşan sıcaklık eğimcesinin belirlenmesi oldukça önemlidir. Bu çalışmada, IEAB' deki sıcaklık dağılımının belirlenmesi için ANSYS yazılımı kullanılmıştır. IEAB'de oluşan en yüksek sıcaklık değeri belirlenmiş, analizler sonucu elde edilen soğuma hızı değerleri, teorik olarak hesaplanan değerler ile karşılaştırılmıştır.
\end{abstract}

Anahtar Kelimeler: Sonlu elemenlar ile modelleme, ANSYS, TIG Kaynağı

\section{Introduction}

Duplex stainless steels (DSS) have equal amount of austenite and ferrite phases. DSS have higher mechanical properties, corrosion resistance in chloride media and general corrosion resistance owing to dual phase structure [1-3].

In welding of DSS, austenite/ferrite phase ratio can vary and various intermetallic phases may occur in weld metal due to excessive heat input. Especially, HAZ is very sensitive against the variation of austenite/ferrite phase ratio and formation of intermetallic phases. Thus, mechanical properties and corrosion resistance of DSS will decrease. Therefore, determination of heat input during the welding and heat flow into the weld metal are critical for identifying the weld metal microstructure. Finite element modelling (FEM) method is used for determining the heat flow and temperature 
gradients into weld metal during the welding process. In FEM, a solid model of weld metal is created and heat flow analysis is run depending on the welding and specimen parameters [3-5].

Various softwares are used in FEM of welding. In this study, FEM was studied in TIG welding of DSS. Also, ANSYS workbench was adapted for determination of heat flow into DSS weld and temperature gradient into HAZ was determined.

\section{Experimental}

ANSYS Workbench 14.5 was used in modelling of heat flow in DSS welding. A solid model of DSS plates were created with 400x 150x10 mm dimension and heat flow analysis were performed in "transient thermal" module. ANSYS Workbench starting page was given in Figure 1.

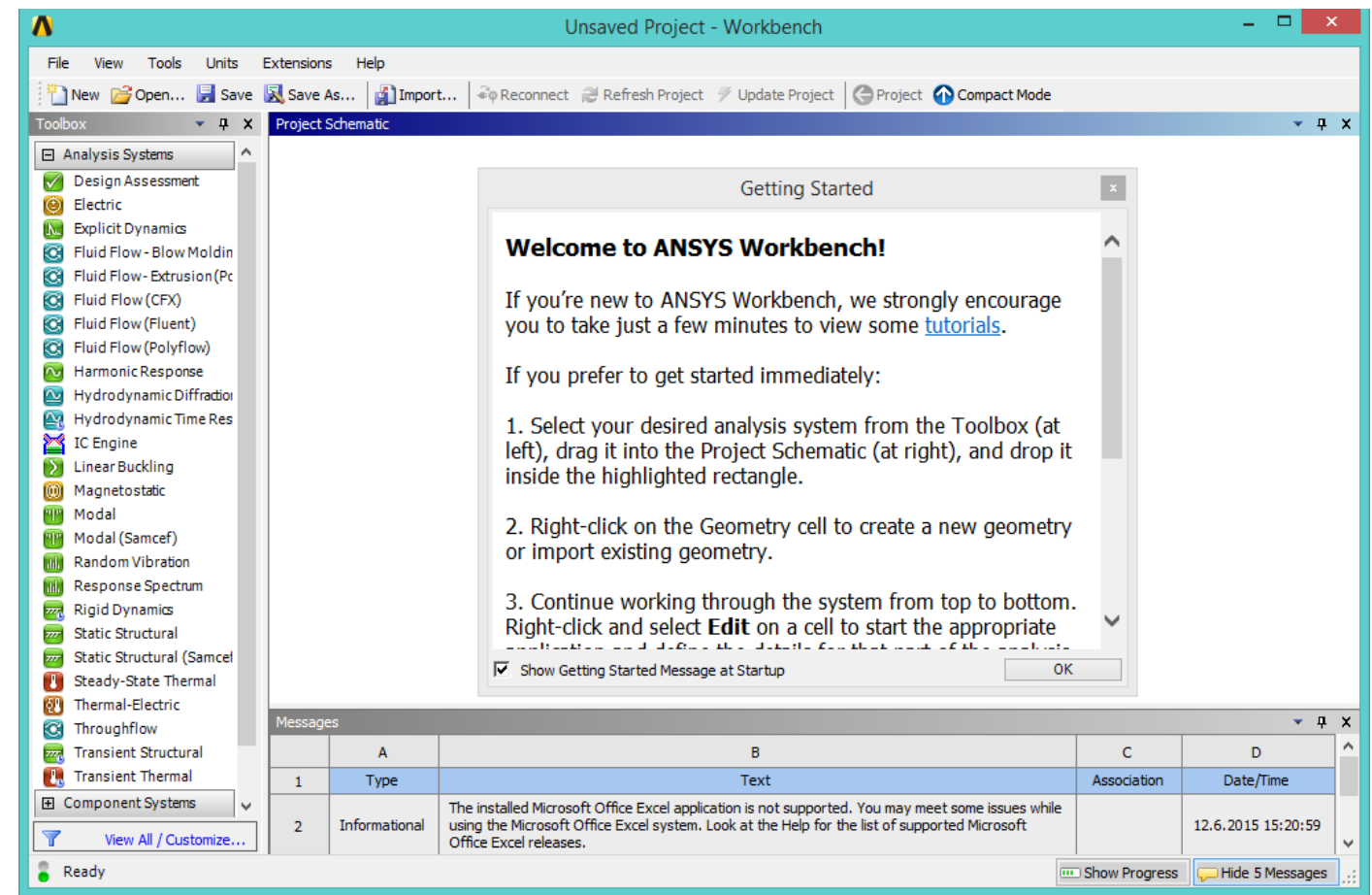

Figure 1. ANSYS workbench starting interface

After selecting the transient thermal module, transient thermal project including material data, solid model and analysis set up was seen as given in Figure 2. 


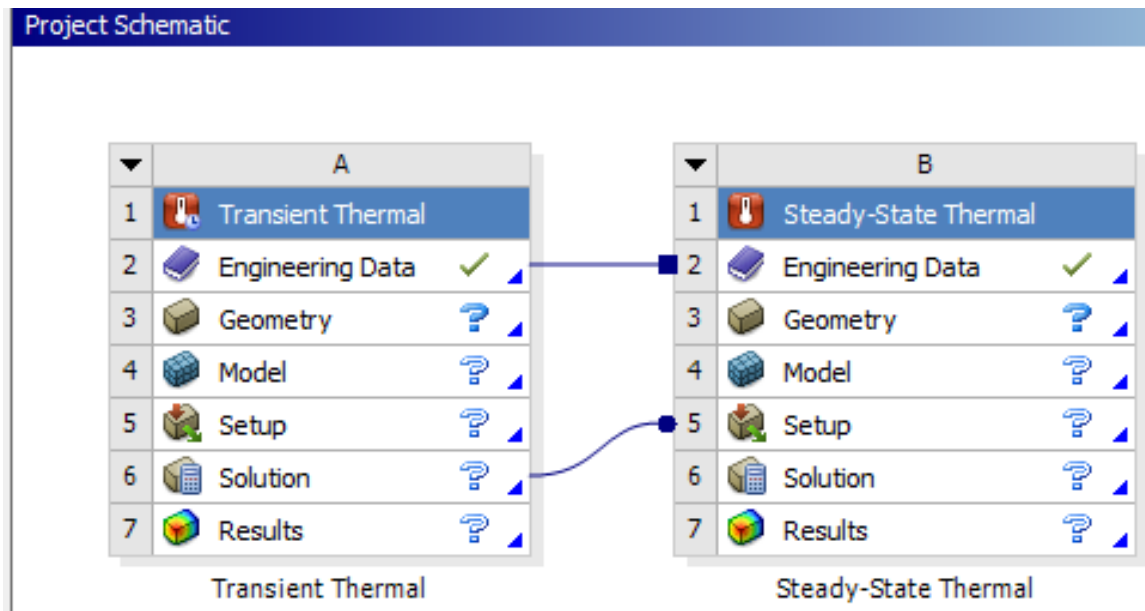

Figure 2. Transient thermal module working page

Analysis were performed with transient thermal module by defining the material properties into software engineering data. Defined material properties were density, specific heat and thermal conductivity values of DSS. After defining the material properties into software library, a solid model of DSS weld was uploaded and also, temperature gradients occurred during the welding was calculated and analysis time was determined depends on the welding time. Welding power was calculated from Equation 1.

$Q=E x I \times f 1$

Where, $\mathrm{Q}$ is heat power $(\mathrm{W}), \mathrm{E}$ is welding voltage $(\mathrm{V}), \mathrm{I}$ is welding current and $\mathrm{f1}$ is welding efficiency determined from welding method.

By creating solid model of DSS, defining the material data into software and determining the analysis time, the welding and material parameters mentioned below was counting into welding FEM analysis:

- Material properties,

- welding current and welding voltage,

- $\quad$ welding method,

- $\quad$ welding speed and time.

\section{Results and Discussion}

Modelling of TIG welding with 200 A welding current, $15 \mathrm{~V}$ welding voltage and $900 \mathrm{~s}$ welding time was performed. Welding efficiency (f1) of TIG is between $0.50-0.60$ and also, f1 was determined as 0.60 in FEM analysis. Welding power in TIG welding was calculated as $1800 \mathrm{~W}$. The temperature gradient generated into HAZ structure was given in Figure 3.

According to FEM analysis, the peak temperature generated into $\mathrm{HAZ}$ was $803{ }^{\circ} \mathrm{C}$. The peak temperature values were $681{ }^{\circ} \mathrm{C}, 706{ }^{\circ} \mathrm{C}, 757{ }^{\circ} \mathrm{C}$ and $784{ }^{\circ} \mathrm{C}$ during the 588 seconds, 646 seconds, 774 seconds and 844 seconds analysis time, respectively.

Also, cooling rates of the analysis were compared with theoretical cooling rate values as seen in Figure 4. Theoretical cooling rate values were calculated form Equation 2. 


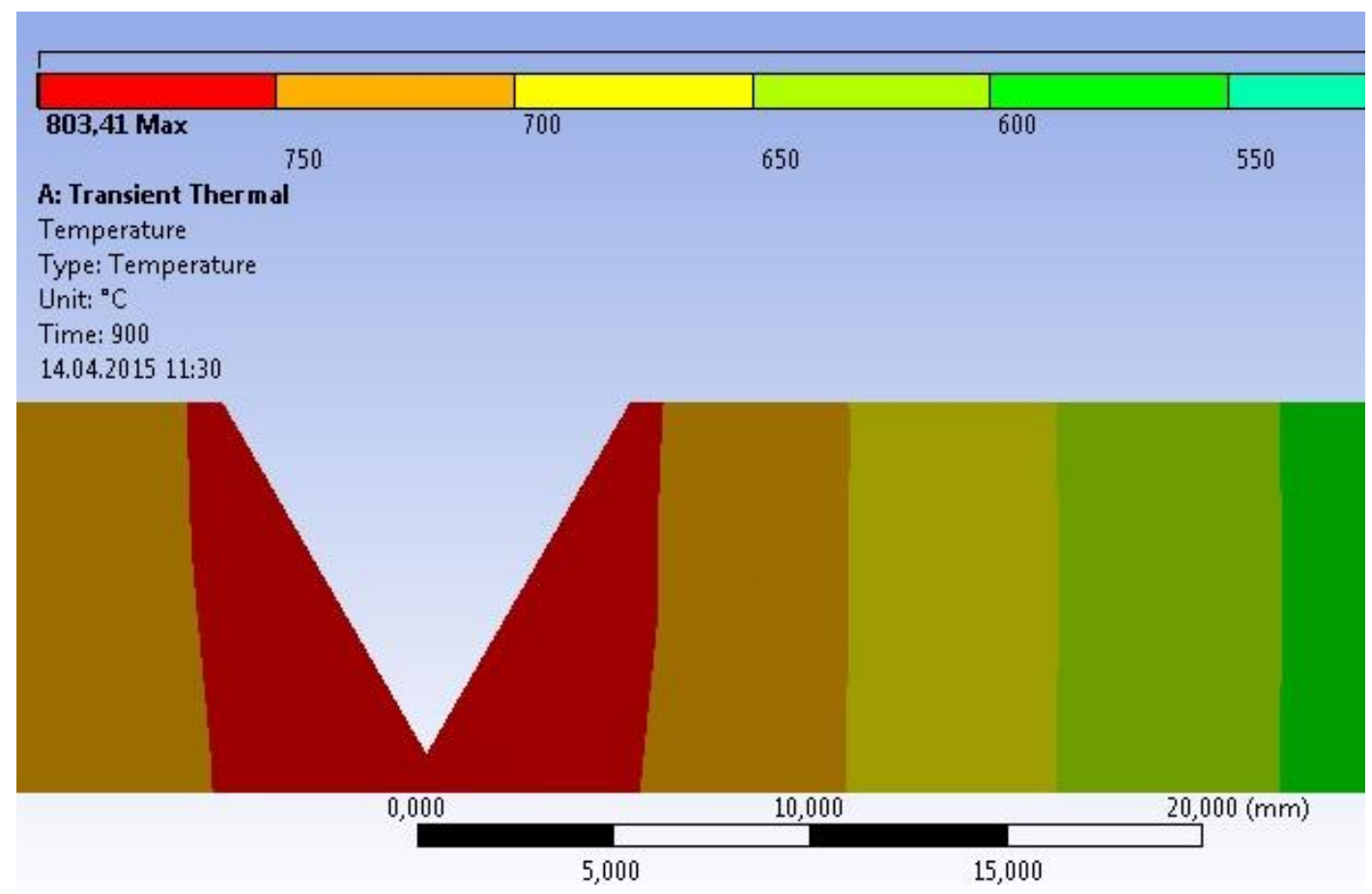

Figure 3. Temperature gradient formed into HAZ

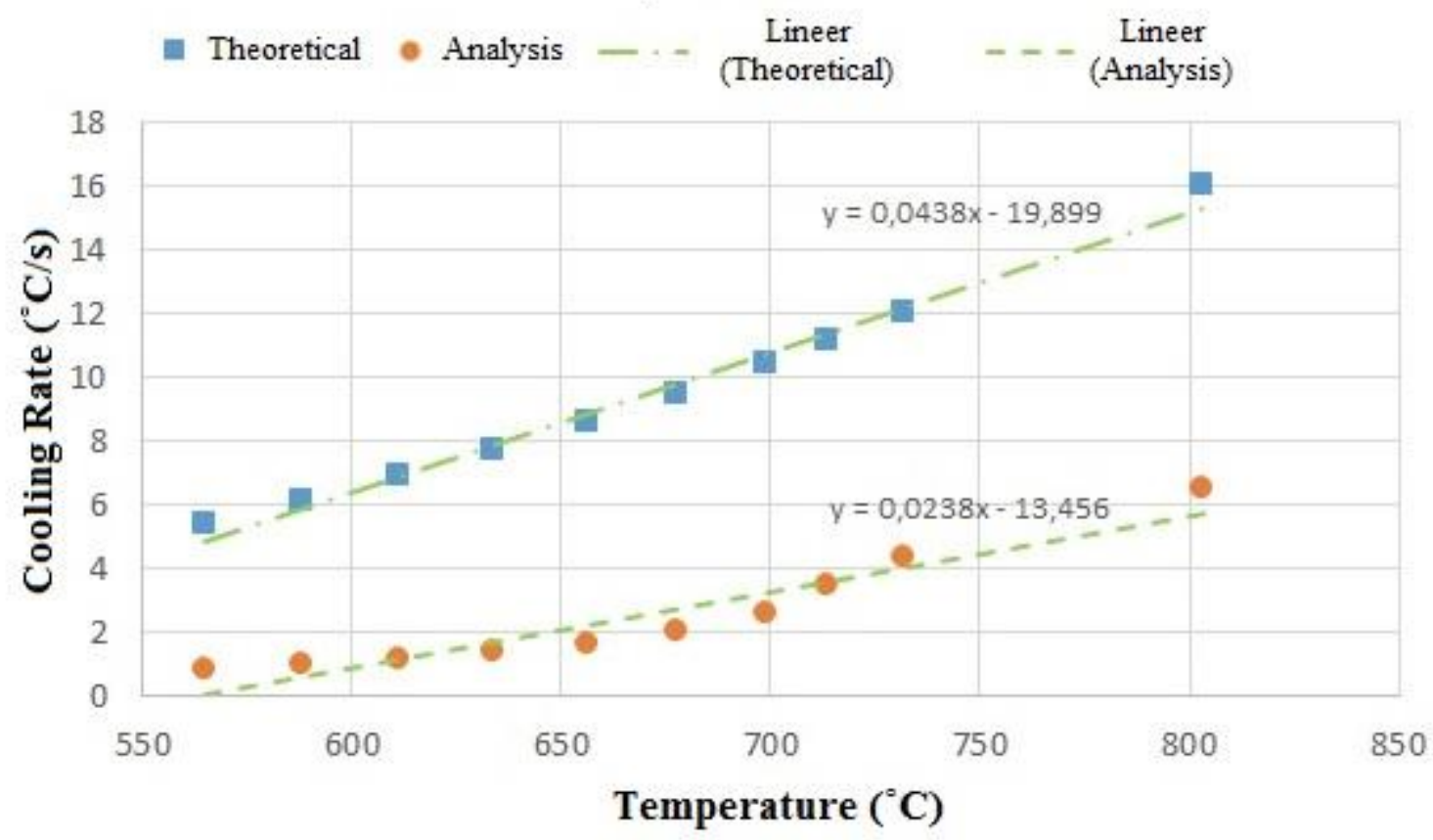

Figure 4. Comparison of theoretical and analysis cooling rates

$R=2 \times \pi \times K \times \rho \times c\left(h / H_{n e t}\right)^{2}\left(T_{c}-T_{0}\right)^{3}$

where, $R$ is cooling rate $\left({ }^{\circ} \mathrm{C} / \mathrm{s}\right), K$ is thermal conductivity $\left(\mathrm{J} / \mathrm{mm}-\mathrm{s}{ }^{\circ} \mathrm{C}\right), T_{c}$ and $T_{0}$ is temperature $\left({ }^{\circ} \mathrm{C}\right)$, $\rho$ is density $\left(\mathrm{g} / \mathrm{mm}^{3}\right), c$ is specific heat $\left(\mathrm{J} / \mathrm{g}{ }^{\circ} \mathrm{C}\right), h$ is thickness $(\mathrm{mm})$.

The slope of lineer characteristics of therotical and analysis cooling rates are similar 


\section{Conclusion}

In TIG welding of DSS, HAZ is very sensitive against the variation of austenite/ferrite phase ratio and formation of intermetallic phases. Thus, determination of temperature gradient is important.

In this study, the peak temperature value and temperature gradient in HAZ generated during the welding was determined. Moreover, theoretical and analysis cooling rates were calculated. Slope of the lineer characteristics of both cooling rate values was similar.

According to experimental results, ANSYS workbench is useful for determining the temperature gradients in welding of DSS, especially in HAZ.

\section{References}

[1] Alvarez-Armas, I., Duplex Stainless Steels: Brief History and Some Recent Alloys, Recent Patents on Mechanical Engineering, 1 (2008) 51-57.

[2] Kısasöz, A., Gürel, S., Karaaslan, A., Effect of Annealing Time and Cooling Rate on Precipitation Processes in a Duplex Corrosion-Resistant Steel, Metal Science and Heat Treatment, 57 (2016) 544-547.

[3] Kısasöz, A., Karaaslan, A., Finite Element Analysis of 2205 Duplex Stainless Steel Welds, Materials Testing, 56 (2014) 795-799.

[4] Asif, M., Shrikrishana, K.A., Sathiya, P., Finite Element Modelling and Characterization of Friction Welding on UNS S31803 Duplex Stainless Steel Joints, Engineering Science and Technology, 18 (2015) 704-712.

[5] El Bartali, A., Evrard, P., Aubin, V., Herenú, S., Alvarez-Armas, I., Armas, A.F., DegallaixMoreuil, S., Strain Heterogeneities Between Phases in a Duplex Stainless Steel: Comparison Between Measures and Simulation, Procedia Engineering, 2 (2010) 2229-2237. 